\title{
A note on the history of the journal
}

\author{
J T Scott
}

The first annual Reports on Chronic Rheumatic Diseases-forerunner of our Annals-was published in 1935 by authority of the British Committee on Chronic Rheumatic Diseases, a specialist body established in 1934 by the Royal College of Physicians of London.

There is a good deal of debate today about the multiplicity of rheumatology journals, but no such thoughts would have been aired at that time, for they were then few in number. A journal called Archives of Medical Hydrology had been first published in London in 1922 and Fysiatricky Vestnik in Prague in 1923. The year 1929 saw the first volumes of Acta Rheumatologica Moscow and Acta Rheumatologica Amsterdam. The first edition of Revue du Rhumatisme et des Maladies Osteoarticulaires appeared in 1934. Details of journals which began their lives subsequently are to be found in 'The literature of rheumatism'. ${ }^{1}$

The aim of the Reports (copies of which are to be found in the Heberden Library at the College) was to bring news of recent research to those interested in chronic rheumatism and thereby to engender further research activity. A regular feature was to be a critical abstract of the year's publications, and various papers in the first Report discussed current topics of interest, such as nomenclature, focal sepsis, allergy, and the role of histamine in treatment. Philip Hench, writing from the Mayo Clinic, reported every year on research from America, and there were reviews of laboratory studies, such as Cecil's work on agglutination of haemolytic streptococci when exposed to the serum of patients with rheumatoid arthritis: not unnaturally the specificity of the reaction was thought to reside in the microbes themselves rather than in the then not yet conceived IgG immunoglobulin which was coating their surface.

Few of the papers would get very near publication today, but one can only admire the enthusiasm and diligence of those earlier workers who, without for the most part very much in the way of academic training, support, or funding, gave so much of their time and energy to advancing rheumatology at that period. A particularly perceptive paper was that of $\mathrm{C} \mathrm{C}$ Okell, professor of bacteriology at University College Hospital, in the 1937 Report: in a critical discussion of vaccine treatment in rheumatoid arthritis he made a strong plea for the statistical evaluation of therapeutic research, this some 10 years before the pioneering study by Peter Armitage and his colleagues into the treatment of tuberculosis with streptomycin and 20 years before the trial carried out by the
Empire Rheumatism Council into the use of gold salts in rheumatoid arthritis.

The 1938 Report was the last. It was announced that the work of the British Committee on Chronic Rheumatic Diseases had been taken over by the Scientific Advisory Committee of the newly formed Empire Rheumatism Council, later to become the Arthritis and Rheumatism Council for Research. There was to be a new journal.

Volume 1, number 1 of The Rheumatic Diseases (very soon to be renamed Annals of the Rheumatic Diseases) appeared in January 1939, the original editorial committee consisting of $\mathrm{Dr}$ C W Buckley, Dr W S C Copeman, and Mr A G Timbrell Fisher. Charles Buckley seems to have been the principal editor: he was senior physician to the Royal Devonshire Hospital at Buxton, Derbyshire, and he was well known as one of the first reputable spa rheumatologists. Will Copeman (shortly to serve in the R.A.M.C. during the war) was consultant rheumatologist at the West London Hospital. Timbrell Fisher was an orthopaedic surgeon at St Stephen's Hospital, Chelsea. The journal was the official organ of the Empire Rheumatism Council, being originally published by $\mathrm{H} \mathrm{K}$ Lewis.

That first issue no doubt reflected areas of interest and progress as they were seen at the time, and for that matter still are. The possible role of viral infection as a causal factor in rheumatoid arthritis is thought about nowadays as much as it was then, but speculation about a relation between rheumatoid arthritis and rheumatic fever on the basis of supposed histological similarity would be seen today as less convincing. The young were making their marks: F Dudley Hart attempting (unsuccessfully) to reproduce subcutaneous nodules, and Oswald Savage measuring oxygen and carbon dioxide tensions in knee joints. E G L Bywaters reviewed Synovial Membrane by D M Kling in terms which were not altogether favourable ('Demur must be made on several points'), the author replying with acerbity in a later issue.

J J R Duthie discussed sociological aspects of the treatment of arthritis following a visit to the United States, and Will Tegner, after a similar visit, described the treatment of rheumatoid arthritis with streptococcal vaccines then being tested at Johns Hopkins. A paper appeared on 'Gout-an unsolved problem'. This it certainly was, with little of our current knowledge of pathogenesis and no conception of modern treatment. Nevertheless, the question raised by the authors - J Barnes Burt and R G Gordonas to what extent urate crystals caused joint damage or to what extent they were formed in
Rheumatology, Charing Cross Hospital, Fulham Palace Road, Hammersmith, London W6 8RF J T Scott 
dystrophic tissue, is one being examined again today by osteoarticular pathologists. Philip Hench continued to write from the United States, describing, for example, the dramatic effect of sulphanilamide in gonococcal arthritis: then current doses of gold were thought to be on the high side and were being reduced to $200 \mathrm{mg}$ weekly. Until the advent of Arthritis and Rheumatism in 1957 there was no major rheumatology journal in North America and the Annals received many papers from across the Atlantic.

The young journal was hit by the second world war with the necessity for economy in paper, and from 1940 to 1943 only two slim issues appeared every year. During the war years each volume extended over a two year period, so that the present volume 50 , which we are celebrating, does not coincide with the 50th anniversary of the journal, which fell in 1989. At the end of the war things improved. At that time the Annals became owned and published by the British Medical Fournal. It does, in fact, hold quite a senior rating among the $14 B M F$ specialist journals, only four being founded previously - the British fournal of Ophthalmology (1917), Archives of Diseases in Childhood (1926), the British Fournal of Venereal Diseases, now Genitourinary Medicine (1925), and the Fournal of Neurology, Neurosurgery, and Psychiatry (1938).

The Heberden Society had been founded in 1936 as a clinical and scientific society for the advancement of the study of rheumatic diseases, and the Annals was adopted as its official organ in 1945, with a close and cordial relation between the society and the journal. The previous year had seen an enlarged editorial commitee, and in 1954 W S C Copeman became the sole editor with Oswald Savage as assistant editor. He was succeeded by myself (1971), H L F Currey (1983), and A K Thould (1988). Over the years the journal maintained and enhanced its position as a leading international organ with an increasing circulation.

We reviewed its aims at my first editorial meeting, contained in the advice to contributors: 'This journal exists to publish work on all aspects of rheumatology and disorders of connective tissue. Laboratory as well as clinical studies are welcome'. In other words, clinical rheumatology, but related aspects of basic science with the main emphasis on original papers rather than reviews (the present editor shows a nice balance here).

What is the function of specialised medical journals? The Annals has been rarely the first to give accounts of major scientific advances, the authors of such discoveries usually requiring rapid publication to a wide readership, hurrying to Nature or the Lancet. For example, the story of cortisone as published in the Annals ${ }^{2}$ was reprinted from a paper published in the Proceedings of the Staff Meetings of the Mayo Clinic, in this case an excellent though unusual way of making this classical work available to British (and other) readers who would be unlikely to see the original paper. 'Annals' are chronicles of events, published regularly (originally annually), which thus by their very nature will contain work which is not necessarily exactly nascent, but which is characterised by full and meticulous documentation. This applies to forms of presentation such as tabulation and particularly illustration: no journal is superior to the Annals of the Rheumatic Diseases in the quality of clinical, radiological, or histological reproduction. The author who submits sloppy pictures, such as, say, a pair of hand radiographs, when what is necessary is a carefully selected metacarpophalangeal joint to make the point under discussion, can expect to receive a sharp editorial rap across his own knuckles. In this way specialist journals serve their own discriminating and knowledgeable readers.

The United Kingdom now has two important rheumatological journals, the Annals and the British Fournal of Rheumatology, which started life as the Annals of Physical Medicine. Both are thriving. The two journals are similar in content but have different owners and publishers. For historical reasons the British fournal of Rheumatology became the official organ of the British Society for Rheumatology. Nothing will change in a hurry, but the question arises as to whether there is a need, or indeed a place, for both. After all, the formation of the British Society for Rheumatology to replace the Heberden Society and the British Association for Rheumatology and Rehabilitation took place after a good deal of stormy discussion and argument, but is now seen as the most natural thing in the world. ${ }^{3}$

Meanwhile, floreant Annales.

1 Morton L T, Bywaters E G L. The literature of rheumatism Ann Rheum Dis 1969; 28: 669-73.

2 Hench P S, Kendall E C, Slocumb C H, Polley H F. The effect of a hormone of the adrenal cortex (17-hydroxy-11. dehydrocorticosterone: compound $E$ ) and of pituitary adrenocorticotrophic hormone on rheumatoid arthritis. Preliminary report. Ann Rheum Dis 1949; 8: 97-104.

3 Anonymous. The British Society for Rheumatology [Editorial]. Ann Rheum Dis 1983; 42: 241-2. 